\title{
Bibliocentre: An Essay in Central Processing at College Level
}

\begin{abstract}
This paper recounts the establishment of a central bibliographic and processing center for twenty community colleges in Ontario. It presents a case history of the beginnings of this venture, including the basic demonstration regarding costs.
\end{abstract}

$\mathrm{T}_{\mathrm{r}}$ He Bibliocentre of the Colleges of Applied Arts and Technology of Ontario came into being as a result of the foundation of these colleges in the spring of 1967. At that time it was announced that twenty colleges were to open their doors in the fall of the year, for students throughout Ontario, beginning a new pattern of higher education that would be a different sort of education from that traditionally offered by the universities and colleges already in being. Although these new colleges were to be primarily concerned with vocational and technical education, the liberal arts, naturally, were not to be neglected. Some people were surprised at the apparent suddenness of the development, although indeed their founding was the result of years of study and preparation by the Applied Arts and Technology branch of the Ontario Department of Education. Each college was made responsible to a local Board of Governors. A Provincial Council of Regents was set up to govern the schools. The Council

Mr. Ready is University Librarian at McMaster University in Hamilton, Ontario. was composed of citizens eminent in their own fields of endeavor. They were backed by the expertise of the Department of Education, under the direction of Norman Sisco and a selected staff of experts.

The colleges came before the buildings that were to house them. They opened in temporary quarters, in converted schools and industrial buildings, even in trailers. The staff was assembled, often just in time to meet a hectic opening day. Among the most difficult staff to find and to hire were librarians with college experience. Yet without librarians there could be no libraries, so it was with a strong sense of urgency that Alexis Jamieson, recently appointed Master and Assistant Librarian at the new Seneca College, returned to McMaster University, where she had formerly been Chief of Public Service, to see what McMaster could do to help Seneca get a library together for opening day in the following September.

The McMaster librarians agreed that if the Seneca library staff, still in process of assembling, would provide them with a list of books needed, the McMaster staff could process them. They re- 
garded this as not too much an intrusion on their own time, and they were doing it for a friend and colleague. They were blithe about it. Some of the blitheness was to wear off during the next few months. Had they known what they were letting themselves in for, they would not have entered into the scheme so easily, so full of goodwill. Yet, now that it is over, it was a library experience to be cherished. It became for all a sort of Agincourt, a feast of Crispian, but at that time, in the spring of the year, it seemed easy going, what they would do for Seneca.

Then, in helping to remove the stone that blocked the progress of that library, they sprouted wings, until the whole sky was full of flying things, books, brickbats and unease. For it soon happened that McMaster librarians became persuaded that they ought to help not only Seneca, but all of the new colleges.

Victor Whatton, of the Department of Education, was concerned with the library situation of the colleges. More than most administrators, he realized the time and effort involved in setting up a library, because he is a graduate librarian as well as an educational administrator. By dint of his cajolement, he persuaded McMaster to do for all the colleges who wanted it what had been agreed upon for Seneca alone. He must have been very persuasive that day at McMaster. Somehow his ebullience carried the day. He infected McMaster with it so much that at times they were sick of it, yet if anyone deserves the palm for getting libraries into the colleges as soon as they did, it is he. $\mathrm{He}$ was the supporter whose confidence and optimism never flagged; indeed, it more than matched McMaster's own. All involved in the project had had little or no experience with any form of higher education save that at a university. Here is a great lesson in library administration, in administration of all kinds! What seems so sensible and rea- sonable on paper, like a battle plan, becomes muddled, torn and marred in practice, with hazards unforeseen, resistance unexpected; invisible elements arise like enemies to foul up the situation.

McMaster had to come to a few decisions if it were to go ahead full steam. The first was to adopt the LC classification, then that acquisitions be pre-processed wherever possible, and that the collections be basic only.

McMaster began at once to find out what was available in pre-processed library material and learned that, while American lists were extremely useful in the areas of technology and applied arts, they failed Canadian library needs in the social sciences and the humanities. Nearly all of their choices were governed by the American system of education which has as one of its goals Americanism, so that McMaster had to choose from non-processed material almost its entire list of humanities and social sciences materials. Additional titles were purchased in Britain in many more copies than Seneca would need, so that there would be copies available if and when some of the other colleges agreed to join. There was already established in Britain at Hatfield in Hertfordshire, a central library processing system controlling the technical college libraries of that county. They were helpful and provided their catalog and data.

The booksellers in Britain accepted the sort of challenge that was inherent in the nature of this project, especially Bertram Rota, bookseller of Savile Row, without whose efforts the project would have failed. Agencies had already been set up for such operations in Britain, had served college library systems before, and there was no time for exploratory deals while this basic library was being established. It has, however, turned out subsequently that Canadian firms get most of the Bibliocentre business. By the end of June McMaster had 
received from the individual colleges promises of $\$ 802,000$.

Gradually, as the books began arriving, a payroll was established, and the processing began. McMaster was recompensed for workers' salaries, save in two extraordinary cases.

The first shipment of books arrived on the 5th of July. These came from Bertram Rota. Already representatives had been to Bro-Dart at Williamsport, Pennsylvania, and to Stacey's at Palo Alto, California, arranging for pre-processed books, and setting up with Programming Services Incorporated the beginnings of computer control.

By the end of October, 74,000 books representing 6,400 titles had been cataloged and delivered to participating colleges. During the summer boxes and boxes of books filled reading rooms, stairways, and study areas to overflowing, since the university library was concurrently acquiring its own books at a great rate, too. The building was already too small, as faculty, administrators, students, and librarians all clambered over boxes or disappeared between crates. These containers, labyrinthine in their accidental set-up, seemed like the maze at Hampton Court, only more so. Yet not a body or a book were lost.

While McMaster answered questions about the scheme and urged the librarians of the colleges to come and help out during these frantic first months, the whole operation aroused a buzz of conjecture and some dismay among librarians throughout the province. Small wonder. Letters were sent to the Department, protesting that the scheme was harebrained, haphazard, and worse. The President of the University was approached about it. The University Librarian was regarded, rightly, as the originator of the fell design. His professional background and capabilities for such a task were queried. Indeed the entire background of all the people involved came under close scrutiny, and some charges were made, but they were mainly caused by apprehension and lack of communication, although there were some with venom in them. . . . Ignorance and fear are fed by rumor, and rumor runs riot when accurate information is hard to come by. Regrettably one could not take time off to answer all or even most of the questions raised; it was a battle with books and time and people.

The administration at McMaster showed enthusiasm for the project as soon as it was broached. They gave freely, not only of permission, but also of space; they regarded it as a function of the university to help establish these libraries. Indeed, the vice-president, whose bailiwick included the McMaster University Library, was as enthusiastic about the scheme as any librarians and he backed it most heartily. The unequivocal support of Norman Sisco, and of Donald Craighead and Victor Whatton was a pleasure.

By August it was obvious that the scheme was going to work. The loose ends were innumerable, and the advent of the college librarians who came upon the scene late, some of whom had had little experience, and were bewildered by it in many cases, exacerbated the situation. It was obvious that many of the books would not be ready for opening day, although they were on the way, but it was the matter of the choice of books arbitrarily presented to them, and the tardiness of distributors, booksellers and publishers, that caused the strain to show through. Many librarians saw the trees and the bushes, the thorns and the other tangles that were bearing down on them, not the wood, the forest of the project. They deserve our sympathy, and some of them supported from the start, pitching in with a will. They were entering into a new sphere of activity; they were being subjected to the angry denunciations of faculty who often expect a book to be delivered and 
processed a day or so after it has been ordered, and they were in make-do quarters with no books, and with no control over what was coming in. Small wonder that many were dubious of McMaster's efforts. Somehow or other all the books were cleared by October and sent on their way, often with McMaster librarians driving the trucks on weekends to get them there on time; even children of librarians were pressed into service, hauling or packing like men.

The new business manager of the university library received his introduction to the intricacies of university library administration by driving a truck to Barrie by way of Peterborough, Belleville, and Kingston, to deliver college books. There were times when he would disappear behind the wheel of a rented Tilden and not be seen for days. He learned more about the roads, the janitorial services, or lack of them, the timbre and temper of Canadian librarians during those few formative months, than anything that has happened to him since. Normal transportation difficulties now seem like a joy ride, even flying the Russell Papers from London to Malton left him unfazed, since that drive to Timmins by way of Sarnia and Sudbury.

With McMaster cleared of books and the project under way, Bibliocentre had to be set up outside of McMaster. Now it was on its own, the creature of the colleges. McMaster did lend the Bibliocentre three catalogers for a while; that was all, more than enough. The president of Ryerson, although his college was not a member of these newly emerging institutions, was generous and far-seeing from the beginning regarding Operation Bibliocentre; it was through his efforts that space was found adjacent to the Ryerson campus in one of their buildings, 101 Gerrard Street E., where the Bibliocentre still operates, with business that is increasing so rapidly that it has become a model for any who contemplate cooperative and/or central processing to observe.

In spring 1969, the professional journals have contained advertisements for the appointment of a Director for the Bibliocentre. They have spelled it out in such a way that some of the challenge and excitement inherent in the situation comes through in the text.

The success of the project has convinced most of the college presidents of the sense of this approach to library economy. A committee of presidents, under the chairmanship of William Newnham of Seneca College, has been made responsible for establishing and controlling the entity created, and which is now formally known as the College Bibliocentre, as it was informally known at the beginning. This committee of presidents has an advisory committee of their college librarians for consultation.

The culmination of the McMaster end of the project came with the publication of a computer-produced book catalog, which gives location and bibliographic information for all the colleges. Some copies are still available at twenty dollars from the College Bibliocentre. It contains 10,000 titles. The next edition, which was scheduled for publication in the summer of 1969 , will contain 40,000 titles, giving some idea of the growth of the Bibliocentre since it left McMaster.

An accounting and information reporting system has been developed, based on computer techniques that allow the Bibliocentre to give information regarding all orders from their receipt to delivery of fully processed books. Between April 1968 and January 1969, the College Bibliocentre processed and delivered over 30,000 books. This, added to the 77,499 previously delivered, is an impressive total and will show up in the next edition of the union book catalog. The average book cost for the initial operation is shown at the end of this article; cost figures have been improved 
Here is a Breakdown of the First Effort:

Number of books:

Book cost:

Processing cost:

Total cost per volume: about 70,000 volumes shipped to 23 locations by October 31 , 1967.

final total of 74,499 volumes shipped by March 1968 .

$\$ 8.23$ average for science, social sciences, technology.

$\$ 5.61$ average for humanities.

$\$ 1.97$ per volume which includes:

1. Creation of basic list.

2. Selection of material and preparation of lists by level of participation.

3. Ordering.

4. Cataloging-including filing 800,000 cards for 23 separate libraries in 5 files per library (accession, shelf, author/title, subject and subject heading lists).

5. Processing.

6. Packing for delivery according to library and level of participation.

7. Delivery.

8. Creation of union catalog with holdings of all material.

9. Conversion of union catalog to machine readable form, including the publishing of the author union catalog.

10. Binding and distribution of 250 copies of author catalog.

Total cost: $\quad \$ 818,945.40$ of which

$112,918.62$ was returned to the colleges

$\$ 706,026.78$

$\$ 9.48$

The College Bibliocentre Schedule of Service Charges is as Follows:

$\$ 1.25$ per transaction (one order for one title at one time regardless of the number of copies).

$\$ 1.50$ per book for cataloging and processing.

$\$ 0.45$ per book for adding entry to Bibliocentre master machine file.

$\$ 1.15$ per book for perma-binding.

$\$ 2.90$ per book for cloth binding.

In addition, there is a 25 percent charge per book for transportation. This includes delivery charges from publisher and/or dealer to us and delivery charges from us to ultimate destination. There is a weekly cumulative printout of the books on order file and the data allows for subsequent publication of book catalogs. Three dollars forty-five cents, therefore, includes the whole technical processing, barring the binding. These costs, of course, are subject to change and afford all sorts of ammunition for criticism, but libraries would be happy to settle for this processing cost, if they were able to achieve it.

and this trend is expected to continue. Of course, there are complaints and delays galore; this is to be expected, just as any anthology of poetry is noted more for its omissions than for the solid body of the work it contains. It is the hangnail, not the mortal blow, which excites the vocal woe. 